\title{
Influence of Various Soil and Water Conservation Methods on the Moisture Balance at Coffee Plant Root Zone
}

\author{
Lina Saraswati ${ }^{1}$, Sugeng Prijono², Budi Prasetya²
}

10.18805/IJARe.AF-703

\begin{abstract}
Background: The study of the moisture balance can be used to suppose the plants water requirement and the plants water use efficiency. The moisture balance influenced by climate factor, therefore climate change can affect the moisture balance especially in rainfed. Therefore, an effort is needed to manage soil moisture in rainfed as a climate change mitigation measure: soil and water conservation. This study aimed to determine the influence of soil and water conservation on the moisture balance in the coffee root zone.

Methods: This study was conducted at people's coffee plantation of Argotirto village, Sumbermanjing Wetan District, Malang Regency, located between 8.2411-8.1443 S and 112.4031-112.4634 E. Observation were made on February to November 2020, divided into observations in the wet season, dry seasons and flowering period. The observation plots consisted of terraced plot (P0), terraced + straight silt pit (P1), terraced + L-shaped silt pit (P2) and terrace + biopore (P3). The observation variables were: soil physical characteristics and moisture balance components there were precipitation, percolation, runoff, evapotranspiration and soil moisture storage.

Result: At P1, the runoff depth was $80.89 \%$ lower and the percolation was $44.22 \%$ higher than P0. The total soil moisture storage at $\mathrm{P} 1$ was $20.06 \%$ higher than $\mathrm{P} 0$ in the dry season, indicating that $\mathrm{P} 1$ could increase the period of surplus moisture in the dry season.

Key words: Climate change, Coffee plant, Soil and water conservation, Soil moisture balance.
\end{abstract}

\section{INTRODUCTION}

The moisture balance in the root zone describes the correlation between soil moisture input-output, which shows the dynamics of changes in soil moisture storage. Studies on the moisture balance in the root zone can examine plant water requirements and water use efficiency (Haberle and Svoboda, 2015). The moisture balance component includes the input of moisture that is precipitation, irrigation and capillary rise, while the outputs of moisture storage are runoff, deep percolation, evaporation and transpiration which influenced by land use type, soil characteristics and climatic factors.

A temperatures enhancement and precipitation patterns change influence soil moisture balance in an area. The Haditiya and Prijono study (2018) shows that the average air temperature in Malang Regency has increased by 0.3$2.3^{\circ} \mathrm{C}$ during the $2014-2016$ period, while the average precipitation tends to decrease by $0.04-3.1 \%$ on $2014-2016$. Previous studies by Iman et al. (2017) projected a risk map of reducing soil moisture availability in the Greater Malang area, showing that the Sumbermanjing Wetan district has a risk of decreasing soil moisture availability in the range of high to very high categories in 2030 . It is suspected to affect growth and plants production, including coffee. Coffee require sufficient soil moisture from the fruitset to fruit development phase (Anand et al., 2014), which shows that soil moisture availability influences the growth and production of coffee. Carr (2001) states that water stress on coffee during the development season will inhibit branch development and reduce flower buds and plant leaf area index. Water stress that occurs in the mid-season can hinder the growth of branch shoots, impacting the reduction of coffee production in the following year (Tesfaye et al., 2015).
${ }^{1}$ Postgraduate Program, Faculty of Agriculture, Brawijaya University, Veteran $^{\text {st }}$ No. 1 Malang, 65145, Indonesia.

${ }^{2}$ Department of Soil Science, Brawijaya University, Veteran ${ }^{\text {st }}$ No. 1 Malang, 65145, Indonesia.

Corresponding Author: Sugeng Prijono, Department of Soil Science, Brawijaya University, Veteran ${ }^{\text {st }}$ No. 1 Malang, 65145, Indonesia. Email: sugengprijono@gmail.com

How to cite this article: Saraswati, L., Prijono, S. and Prasetya, B. (2022). Influence of Various Soil and Water Conservation Methods on the Moisture Balance at Coffee Plant Root Zone. Indian Journal of Agricultural Research. DOI: 10.18805/IJARe.AF-703.

Submitted: 22-10-2021 Accepted: 22-12-2021 Online: 12-01-2022

Therefore, efforts are needed to improve the resilience of rainfed, one of which is soil and water conservation which can decrease runoff and soil erosion, increase soil moisture storage and soil fertility thereby increasing land productivity (Wolka et al., 2018). Hydrologically, the principle of soil and water conservation is to reduce the rainwater loss through runoff to increase soil moisture storage. In general, part of rainwater that reach to the soil surface will infiltrate, stored in root zones that plants can use for growth, others will experience runoff. This runoff can be stored and conserved for reuse in the dry season.

Several soil and water conservation practices include making terraces on rainfed with slopes, making silt pit and making biopore. Study by Prijono and Bana (2015) showed that making terraces followed by weed removal at coffee plantation turned out to have higher moisture stores (3343 to $335 \mathrm{~mm}$ ) than the coffee plantation that was not created with terraces and followed by weed removal (3316 to 3326 
$\mathrm{mm}$ ). Study by Satibi et al. (2019) showed that the silt pit at coffee plantation could increase the soil moisture content (45.91\%) when compared to the coffee plantation without the silt pit $(28.23 \%)$; thereby increased the land productivity by $7,3 \mathrm{Mg} \mathrm{ha}^{-1}$.year ${ }^{-1}$ on the plots with silt pit; while the productivity land on the plots without silt pit was 4,8 Mg.ha-1.year'. Sari (2017) mentions that biopore can increase the activity of soil organisms, thereby increasing soil porosity and infiltration capacity so that soil moisture storage also increases. This study aimed to determine the effects of several techniques of soil and water conservation on the moisture balance in the coffee root zone.

\section{MATERIALS AND METHODS}

This study was conducted in the people's coffee plantation of Argotirto village, SumbermanjingWetan District, Malang Regency, located between 8.2411-8.1443 S and 112.4031112.4634 E (Fig 1). Laboratory analysis was carried out at the Physics Laboratory of the Soil Department, Faculty of Agriculture, Brawijaya University, Malang, Indonesia. The description of the soil morphology shows that the soil in the study area belongs to the Inceptisol order that is Typic Humudepts, soil texture is Silty Clay. The topography at the study site is sloping with an average slope of $23-40 \%$. The climate in the study area is monsoon with an average rainfall of 1398-3196 mm.year ${ }^{-1}$ and an average temperature of $25^{\circ}$ $\mathrm{C}-27^{\circ} \mathrm{C}$.

This study was conducted from February to November 2020, divided into three observation periods: rainy (RS) on February - May 2020, dry (DS) on June - August 2020 and flowering (FP) on October - November 2020. There were four observation plots (Fig. 2) with different soil and water conservation, namely the bench terrace plot (P0), the bench terraced + straight silt pit plot (P1), the bench terraced + Lshaped silt pit plot (P2) and the bench terraced + biopore (P3).

Input and output data in the moisture balance were needed to know the dynamics of the moisture balance in the coffee root zone. The moisture balance input was obtained by observing precipitation $(P)$, was measured using a manual ombrometer (Prijono, 2009) daily. Whereas moisture balance output was obtained by estimating percolation (D), runoff $(R)$ and actual evapotranspiration (ETa) variables. The $R$ depth was carried out on each replicate plot by making runoff plots (Prijono, 2009) measured every morning after rainy day. The $D$ process estimated by Darcy equation (equations 1 and 2). First, analysis hydraulic potential gradient at a soil profile depth of $80-100 \mathrm{~cm}$. This study uses SPAW model (Saxton and Rawls, 2006) to determine the hydraulic potential of the soil. If the hydraulic potential at a depth of $100 \mathrm{~cm}$ lower than a depth of $80 \mathrm{~cm}$, it is suspected that $D$ has occurred, on the other hand if the hydraulic potential at a depth of $80 \mathrm{~cm}$ is lower than a depth of $100 \mathrm{~cm}$, it is suspected that a capillary rise has occurred. After the results of the analysis show the occurrence of the $D$ process the next step is to calculate the $D$ depth using the Darcy equation. The ETa was calculated by the moisture balance equation (equation 3 ). Observations of soil moisture content (SM) variables were carried out to examine the dynamics of SM changes in various soil and water conservation methods. The SM was measured using the gravimetric method, soil sample was carried out at one point for each replicate plot at intervals of $10 \mathrm{~cm}$ to a depth of $100 \mathrm{~cm}$ to determine the total SM (equation 4) in the coffee root zone where the average coffee root depth is $150 \mathrm{~cm}$. The data obtained were then analyzed using analysis of variance (ANOVA) and 5\% LSD test.

$$
\begin{gathered}
q=-K(\theta) \frac{d H}{d z} \\
D=q x t
\end{gathered}
$$

Note: $q=$ volume of the water passing through the area $\left(\mathrm{cm}\right.$. day $\left.^{-1}\right) ; \mathrm{K}(\theta)=$ unsaturated hydraulic conductivity; $\mathrm{dH}$ =gradient of hydraulic potential; $d Z$ =gradient of depth at which the hydraulic potential was measured $(\mathrm{cm}) ; \mathrm{D}=$ percolation depth $(\mathrm{mm})$ and; $\mathrm{t}=$ period of percolation (days of percolation process).

$$
\Delta S=P-D-R-E T a \text {, then ETa }=P-D-R-\Delta S
$$

Note: $\mathrm{ETa}=$ Actual evapotranspiration $(\mathrm{mm}) ; \Delta S=$ Gradient in soil moisture storage $(\mathrm{mm}) ; \mathrm{P}=$ Precipitation $(\mathrm{mm}) ; \mathrm{D}=$ Percolation $(\mathrm{mm})$, dan; $\mathrm{R}=$ Runoff $(\mathrm{mm})$.

$$
\begin{aligned}
S= & 150\left(\theta_{10}\right)+100\left(\theta_{20}+\theta_{30}+\theta_{40}+\theta_{50}+\theta_{60}+\theta_{70}+\theta_{80}+\theta_{90}\right) \\
& +50\left(\theta_{100}\right) \mathrm{mn}
\end{aligned}
$$

Note: $\theta=$ volumetric moisture content $\left(\mathrm{cm}^{3} \cdot \mathrm{cm}^{-3}\right), S=$ total soil moisture storage $(\mathrm{mm})$,

\section{RESULTS AND DISCUSSION}

\section{Soil moisture storage}

The moisture content of the soil profile in the rainy was higher than dry season in all observation plots (Fig 3 ). This is presumably because the source of soil moisture in the study site comes from rainwater so that during the dry there is no additional soil moisture input while the process of soil moisture loss through evapotranspiration continues. Moisture content at a depth of $0-15 \mathrm{~cm}$ soil profile is higher than $85-$ $100 \mathrm{~cm}$ in all observation plots (Fig 3). The high soil moisture at a depth of $0-15 \mathrm{~cm}$ is thought to be due to the high percentage of sand in that layer. Sandy soil has a lot of macro pore which affects the increase in infiltration. On the other hand, the low soil moisture at a depth of $85-100 \mathrm{~cm}$ is thought to be due to an increase in the percentage of clay in that layer where the clay inhibits the rate of soil infiltration.

Table 1 shows that the difference of total SM in all observation plots was not significant in RS. Total SM was significantly different between all observation plots in DS (Table 1). P1 tended to have high SM and was not significantly different from P3 in DS. This is presumably due to silt pit accommodated runoff during wet season, which made the infiltration period longer. Study by Satibi et al. (2019) showed that the soil moisture content in coffee fields 


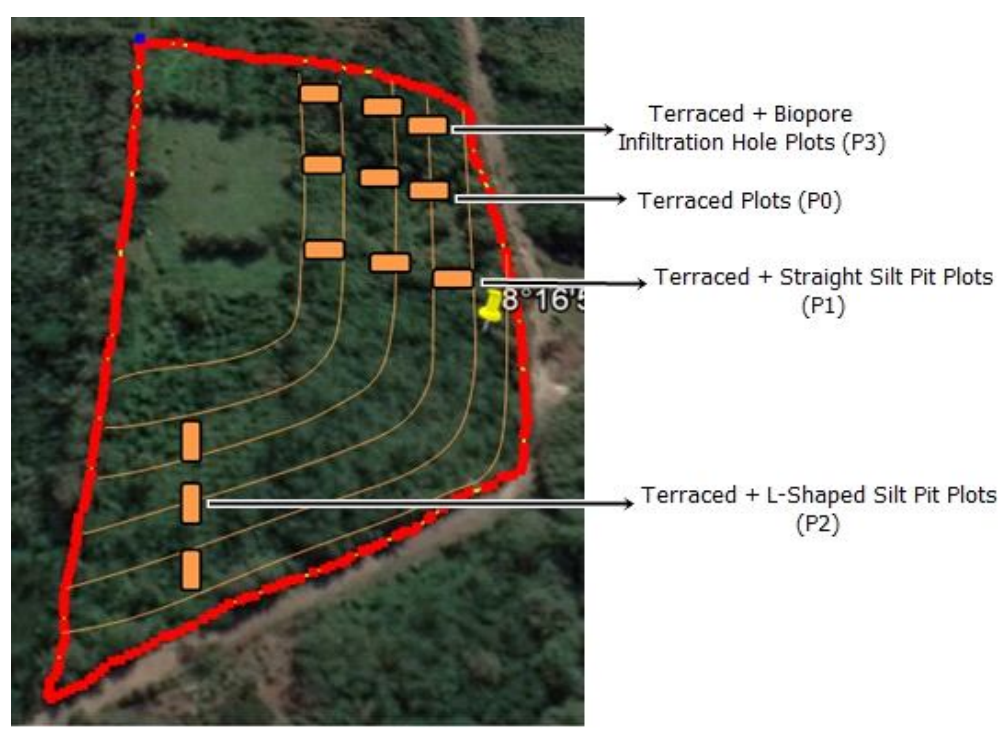

Fig 1: Location site.

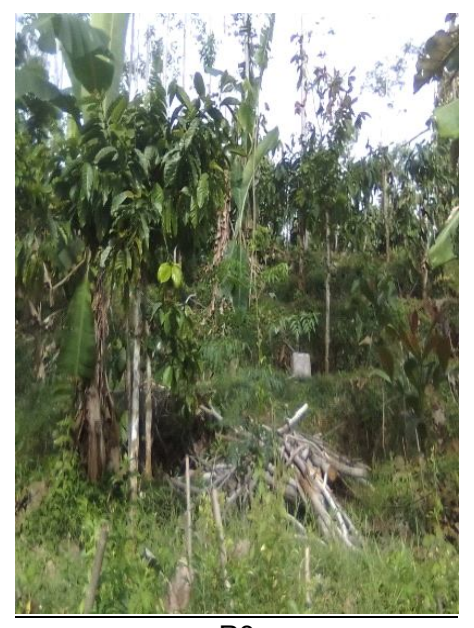

P0

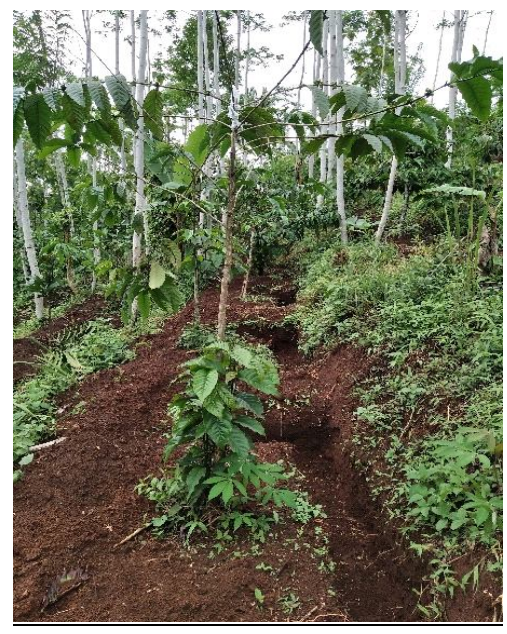

$\mathrm{P} 2$
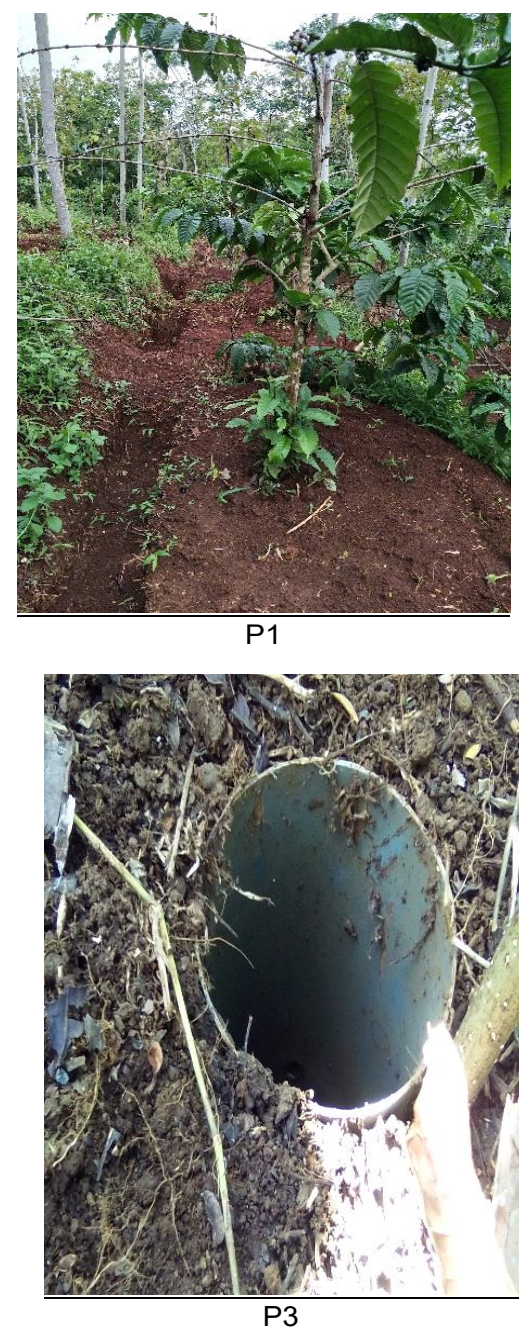

Fig 2: The treatment plots of different soil and water conservation methods. 
with silt pit was higher $(45.91 \%)$ when compared to coffee fields without silt pit (28.23\%). The total SM was significantly different between all treatment plots in FP on observations of $19^{\text {th }}$ (Table 1). The high total SM in FP was found in P3 and was significantly different from the other observation plots. The low total SM in FP was found in PO but not significantly different from $P 1$ and $P 2$. The increase in SM at P3 was thought to be due to infiltration increase due to the compost addition in biopore. Compost was thought to improve the aggregate and soil structure around the biopore so that improve soil porosity and increase water infiltration. Study by Khoirunisa et al. (2014) showed an increase infiltration rate in soil with biopore that is 1129.91 liters.minute ${ }^{-1}$, while the soil without biopore had infiltration rate of 86.66 liters.minute ${ }^{-1}$.

\section{Moisture balance in the coffee root zone}

The $\mathrm{P}$ affects the regional and root zone moisture balance because it is an input component in analyzing the moisture balance. Table 2 shows monthly $P$ in 2020 at the study site, where low P occurred on October-November. Study by Haditiya and Prijono (2018) showed that the peak of $P$ was in Malang Regency occurred on December-January, while the low P occurred on September-October in 2014-2016. P was the only SM input in the study area, which indicated that the study site was rainfed.

The $\mathrm{R}$ depth in P3 was higher than in other plots in 2020 (Table 2). This doesn't match objectives of soil and water conservation, one of which was to reduce the $R$. The high $\mathrm{R}$ depth in $\mathrm{P} 3$ was thought to be since there was only one biopore in each observation plot. $\mathrm{R}$ was reduced by $75.04 \%$ in a plot with two biopore, whereas a plot with three biopore could decrease $\mathrm{R}$ by $93.42 \%$ (Victorianto et al., 2014), indicating that the number of biopore affected $R$ depth.

$D$ is the water movement out of the root zone. $D$ intensity in P2 was higher than the other plots (Table 2). The D process at the study site is influenced by $P$ because during the rainy, there is a percolation process in all observation plots. The average monthly $D$ rate is influenced by adequate $P$, where the $D$ process increases in rainy and decreases in dry (Long and Koontanakulvong, 2019).

Most of SM is lost through evapotranspiration process (Krishna, 2019). ETo indicates the environmental requirement for evaporation influenced by climatic factors (Katua and Pasupalak, 2018). Meanwhile, ETa shows crop water requirements controlled by climatic and plant factors (Prijono, 2009). ETa of coffee during rainy was higher than dry and flowering (Table 2). The high ETa in rainy was thought to be because coffee in the study site entered the mid to late season which have the plant coefficient $(\mathrm{Kc})$ increased so that the plant evapotranspiration also increased. Meanwhile, in dry, the coffee entered the harvest to initiation phase. The Kc of coffee was low, so the plant evapotranspiration decreased.

Climate change phenomenon affects the growth and production of coffee either directly or indirectly. One of the efforts to mitigate of climate change in coffee plantations is to apply soil and water conservation technology. Through

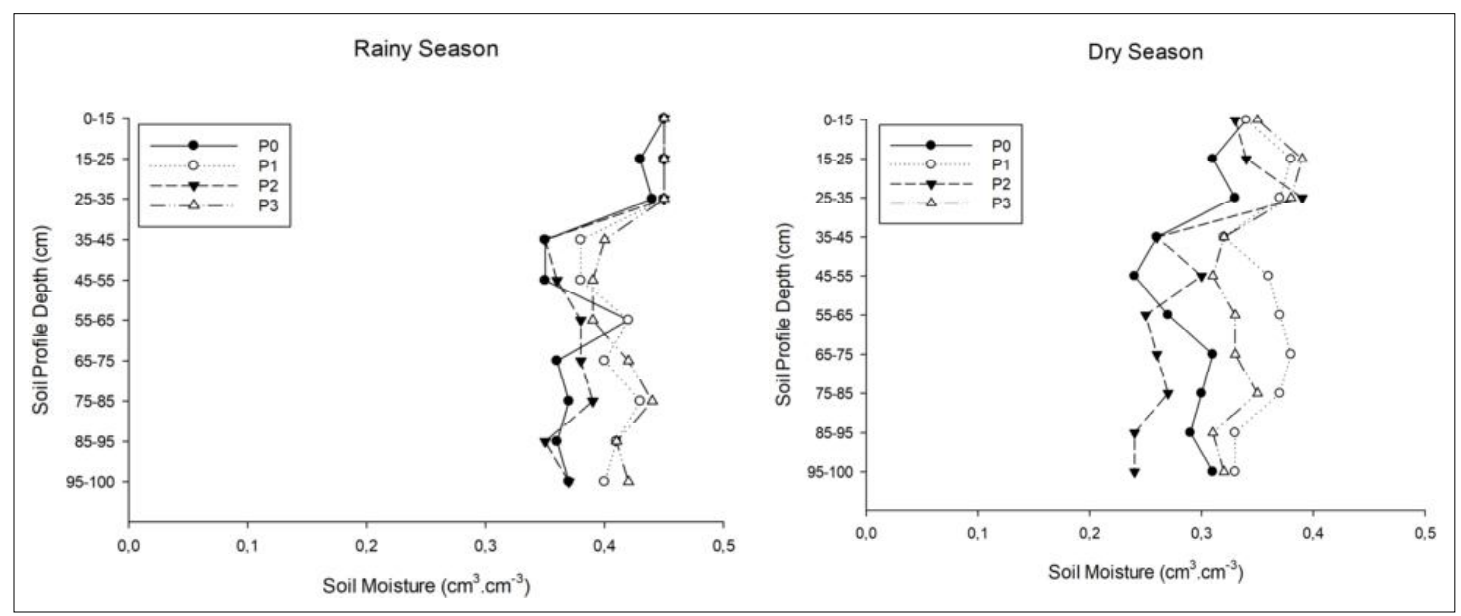

Fig 3: Soil Moisture in rainy and dry season.

Table 1: Total soil moisture storage $(\mathrm{mm})$ in plots of different soil and water conservation practices in the rainy, dry season and flowering.

\begin{tabular}{lcccccr}
\hline \multirow{2}{*}{ Plot } & \multicolumn{3}{c}{ RS } & \multicolumn{2}{c}{ DS } & FP \\
\cline { 2 - 7 } & $15^{\text {th }}$ Feb & $17^{\text {th }}$ May & $07^{\text {th }}$ Jun & $30^{\text {th }}$ Aug & $19^{\text {th }}$ Oct & $23^{\text {rd }}$ Nov \\
\hline P0 & 377.92 & 376.51 & $331.78 \mathrm{a}$ & $293.36 \mathrm{a}$ & $320.80 \mathrm{a}$ & 381.11 \\
P1 & 380.47 & 400.27 & $396.70 \mathrm{c}$ & $355.36 \mathrm{~b}$ & $357.48 \mathrm{a}$ & 385.50 \\
P2 & 397.60 & 380.37 & $348.43 \mathrm{ab}$ & $297.56 \mathrm{a}$ & $340.88 \mathrm{a}$ & 398.66 \\
P3 & 404.76 & 384.06 & $379.91 \mathrm{~b}$ & $339.41 \mathrm{ab}$ & $385.58 \mathrm{~b}$ & 411.73 \\
\hline
\end{tabular}

Note: Numbers accompanied by different letters in the same column show significantly different through the $5 \%$ LSD test. 


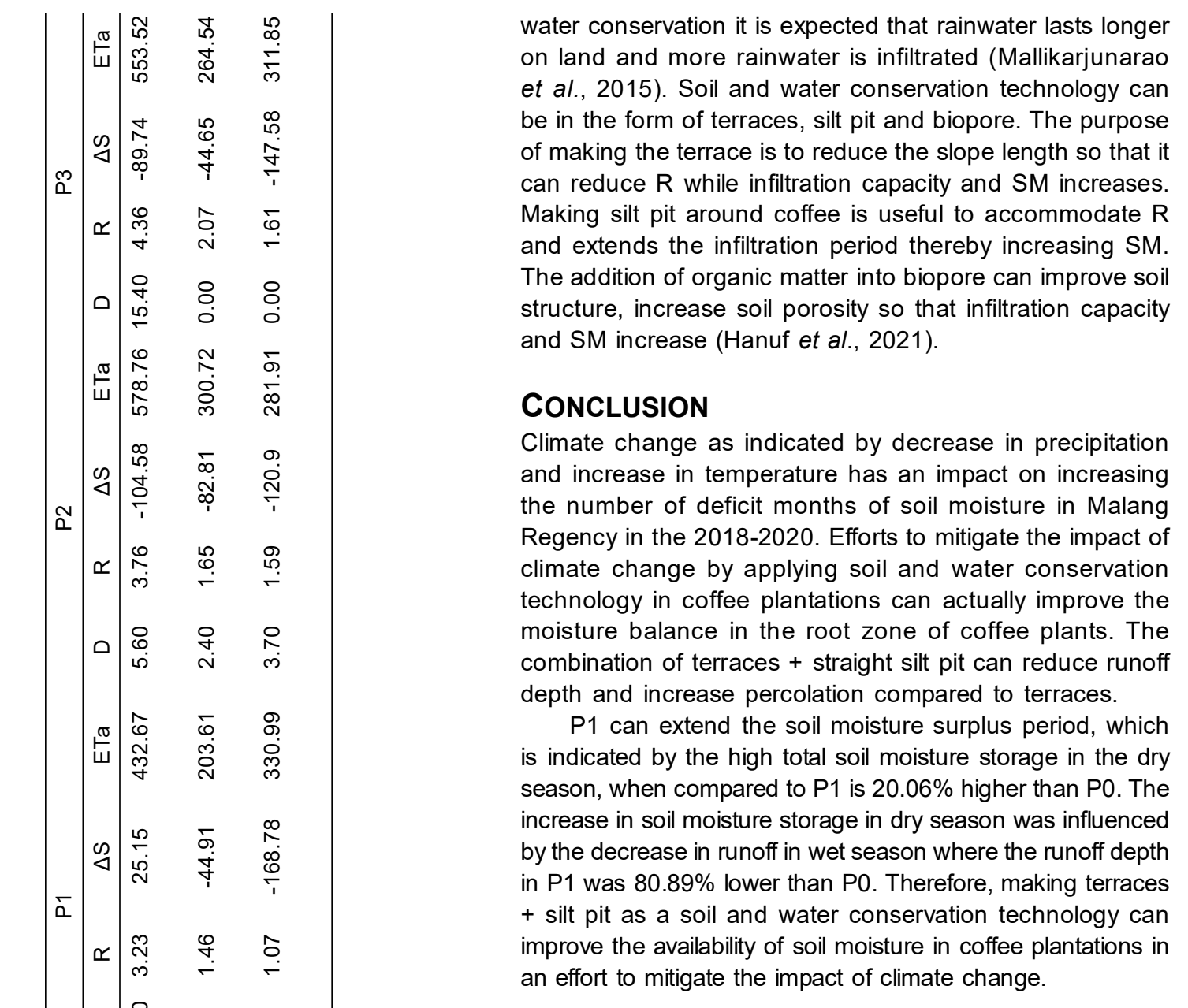

\section{ACKNOWLEDGEMENT}

This study was funded by Professor Grant from the Faculty of Agriculture, Brawijaya University, Malang

\section{REFERENCES}

Anand, C.G., Kumar, P., andD'souza, G.F. (2014). Pre-mature fruit drop and coffee production in India: A review. Indian Journal of Plant Physiology. 19(3): 230-237. https://doi.org/ 10/ 1007/s40502-0140102-y

Carr. M.K.V. (2001). The water relations and irrigation requirements of coffee. Expl Agric. 37: 1-36. DOI: 10.1017/S00144797 01001090.

Haberle, J. and Svoboda, P. (2015). Calculation of available water supply in crop root zone and the water balance of crops. Contributions to Geophysics and Geodesy. 45(4): 285298. doi: 10.1515/congeo-2015-0025.

Haditiya, F.R. dan S. Prijono. (2018). Simulasi Dampak Perubahanlklim TerhadapKetersediaan Air TanamanTebu Di Wilayah Malang. Jurnal Tanah dan Sumberdaya Lahan. 5(1): 663672. https://jtsl.ub.ac.id/index.php/jtsl/article/view/184.

Hanuf, A.A., Prijono, S. and Soemarno, S. (2021). Improvement of soil available water capacity using biopore infiltration hole with compost in a coffee plantation. Journal of Degraded and Mining Lands Management. 8(3): 2791-2799. https:// doi,org/10.15243/jdmlm.2021.083.2791. 
Iman, M.I., Riawan, E., Setiawan, B. and Abdurahman, O. (2017) Air Tanah Untuk Adaptasi Perubahan Iklim Di Malang JawaTimur: Penilaian Risiko Penurunan Ketersediaan Air. Ris.Geo.Tam. 27(1): 47-64. DOI: http://dx.doi.org/ 10.14203/risetgeotam2017.v27.438.

Katua, R. and Pasupalak, S. (2018). Comparison of methods for estimation of reference evapotranspiration in north-central plateau zone of Odisha. Indian J. Agric. Res. 52(2): 187190. https://arccjournals.com/journal/indian-journal-ofagricultural-research/A-4702.

Khoirunisa, N., Wardana, Z.A. and Susilawati, S.A. (2014). Pengaruh Lubang Resapan Biopori Terhadap Laju Infiltrasi dan Kelimpahan Mikroorganisme Tanah. Universty Research Coloquium, 2014, 1-10. https://www.researchgate.net ) publication > 326082665 .

Krishna, P.R.A. (2019). Evapotranspiration and Agriculture-A review. Agricultural Reviews. 40(1): 1-11. https://arccjournals.com/ journal/agricultural-reviews/R-1848.

Long, T.T. and Koontanakulvong, S. (2019). Deep Percolation Charactertistics via Soil Moisture Sensor Approach in Saigon River Basin, Vietnam. International Journal of Civil Engineering and Technology. 10(03): 403-412. http:// www.iaeme.com/jimet/issues.asp?JType=IJCIET and VType $=10$ and IType=3.

Mallikarjunarao, K., Pradhan, R. and Das, R.K. (2015). Dry land techniques for vegetable productionn in India- A review. Agricultural Reviews. 36(3): 227-234.

Prijono, S. (2009).Agrohidrologi Praktis. Lembaga Cakrawala Indonesia, Malang. 168p.
Prijono, S. and Bana, S. (2015). Study of Soil Moisture on Coffee Plantation in Dry Land Using Neutron Probe in Malang, East Java. Bull. Env. Pharmacol. Life Sci. 4(2): 135-143. http://bepls.com/jan2015/25.pdf.

Sari, N.P. (2017). Aplikasi Biopori di Perkebunan Kopi danKakao. Warta Pusat Penelitian Kopi danKakao Indonesia. 29(1): 11-13. https://iccri.net/staff/niken-puspita-sarisp/.

Satibi, M., Nasamsir and Hayata. (2019). Pembuatan Rorak pada Perkebunan Kopi Arabica (Coffea arabica) Untuk Meningkatkan Produktivitas. Jurnal Media Pertanian. 4(2): 74-80. DOI: http://dx.doi.org/10.33087/jagro.v4i2.85

Saxton, K.E. and Rawls, W.J. (2006). Soil water characteristic estimates by texture and organic matter for hydrologic solutions. Soil Sci. Soc. Am. J. 70: 1569-1578. DOI: 10.21 36/sssaj2005.0117.

Tesfaye, S.G., Ismail, M.R., Ramlan, M.F., Marziah, M., Kausar, H. and Hakim, M.A. (2015). Effect of water deficiency on growth and dry matter yield of selected in robusta coffee (Coffea canephora) clones in Malaysia. Journal of Environmental Biology. 36(5): 1239. http://www.fspublishers.org I.../6.pdf.

Victorianto, E., Qomariyah, S. and Sobriyah. (2014). Pengaruh Lubang Resapan Biopori Terhadap Limpasan Permukaan. E-Jurnal Matriks Teknik Sipil, September 2014, 423-430. https://jurnal.uns.ac.id/matriks/article/view/37411.

Wolka, K., Mulder, J. and Biazin, B. (2018). Effects of soil and water conservation techniques on crop yield, runoff and soil loss in Sub-Saharan Africa: A review. Agricultural Water Management. 207: 67-79. https://doi.org/10.1016/ j.agwat.2018.05.016. 